\title{
CAUSE AND SIGNIFICANCE OF SEASONAL VARIATION IN THE HAMORRAGIC TENDENCY IN THE NEWBORN
}

\author{
BY \\ E. KERPEL-FRONIUS, F. VARGA, AND E. KÁTAI PÁL \\ (From the University's Children's Clinic, Pécs, Hungary)
}

The discovery of vitamin $K$ led to the hope that its use would be an important step forward in the prophylaxis of haemorrhagic disease of the newborn and possibly also of intracranial haemorrhage. Its value in the latter, however, has proved to be extremely limited (Willi, 1942; Dyggve, 1947). It was, therefore, felt desirable to search for other possible factors concerned with haemorrhagic states in the newborn.

During a period of five years, over 10,000 newborn infants were investigated at the University's Obstetrical Clinic at Budapest, and a definite seasonal variation in the incidence of melaena, cerebral haemorrhage, and cephalhaematomata was observed (Kerpel-Fronius, 1944). Such a seasonal incidence has for many years been recognized in the case of melaena neonatorum, with a peak period in winter and spring (McCollum, 1928; Hirano, 1932; Kepila and Leppo, 1937; Winkler, 1939). This paper concerns 300 newborn infants with cerebral haemorrhage or cephalhaematomata in whom a similar seasonal incidence was observed.

Waddell and Lawson (1940), from an analysis of deaths due to birth-injury, found the highest mortality in the winter months. It may therefore be assumed that the newborn infant possesses an efficient anti-haemorrhagic factor in the summer and autumn and that this factor diminishes considerably in winter and spring. It has been calculated that the protective influence of the summer is so potent that if all the 10,000 infants seen at the Budapest clinic had been delivered during the summer months the incidence of cerebral haemorrhage would have been halved (Kerpel-Fronius, 1944).

\section{Factors Relevant to Seasonal Variation}

In considering the problems of haemorrhagic disease of the newborn in relation to seasonal variations there are three factors which are relevant: firstly the degree of trauma, secondly the efficiency of the clotting mechanism, and thirdly the fragility of the capillaries. The first cannot be the cause of any seasonal variation. The second certainly can. The most marked prothrombin deficiency has been observed during winter and spring (Waddell and Lawson, 1940; Lehmann, 1944). That the third factor may also be causative is suggested by the frequency of conjunctival haemorrhages. These haemorrhages are petechial and originate from rupture of capillaries during labour and are presumably independent of fluctuations in prothrombin level. They were observed in 196 infants of 1,008 born in one year and showed a high peak in winter and spring, closely parallel to the incidence of cerebral haemorrhage and cephalhaematomata, so that it may be assumed that capillary fragility may also play an important part in the origin of the latter.

\section{Capillary Fragility}

To obtain further information about the influence of the seasons on capillary fragility, 233 healthy children were examined in one year and the data obtained are shown in table 1 .

TABLE 1

SEASONAL INCIDENCE OF CAPILLARY FRAGILITY IN

\begin{tabular}{|c|c|c|c|c|c|c|}
\hline & \multicolumn{3}{|c|}{ Negative pressure cm. Hg. } & \\
\hline Months & 10 & 15 & 20 & 25 & 30 & \\
\hline & & \multicolumn{2}{|c|}{ Number of cases } & & $\begin{array}{c}\text { Percentage of } \\
\text { children with } \\
\text { fragile capillaries }\end{array}$ \\
\hline Jan., Feb. & 2 & 8 & 13 & 9 & 8 & 25 \\
\hline Mar., April & 4 & 13 & 6 & 8 & 8 & $43 \cdot 5$ \\
\hline May, June & 5 & 5 & 10 & 13 & 6 & $25 \cdot 6$ \\
\hline July, Aug. & 1 & 3 & 21 & 11 & 4 & 10 \\
\hline Sept., Oct. & 1 & 4 & 17 & 10 & 5 & $13 \cdot 5$ \\
\hline Nov., Dec. & 1 & 4 & 8 & 12 & 13 & $13 \cdot 1$ \\
\hline
\end{tabular}

Borbély's negative pressure-suction method was used (Borbély, 1930) and the smallest negative pressure that caused visible petechiae was determined. Haemorrhage occurred in all cases at negative pressures varying between 10 and $30 \mathrm{~cm} . \mathrm{Hg}$. Pressures below $15 \mathrm{~cm}$. may be considered low. In thirty-two out of fifty-one cases of low pressure, Rumpel-Leede's test, using a positive pressure of $40 \mathrm{~mm}$. Hg. for 30 minutes, was equally positive. 
In 182 cases with resistant capillaries, as judged by the suction test, Rumpel-Leede's test was invariably negative also.

The evidence presented in table 1 shows a decided seasonal variation in capillary fragility. The number of children with fragile capillaries increases in winter and shows a peak in early spring. The two extremes were found in March and August. In the month of March petechial bleeding, using negative pressures below $15 \mathrm{~cm}$. $\mathrm{Hg}$., appeared on the skin of every second child, in August only on every twentieth. This is in agreement with some similar observations by Roberts et al. (1937).

The figure shows the curves of the seasonal incidence of 150 cases of cerebral haemorrhage and 152 cases of cephalhaematoma as compared with the curve of the incidence of fragile capillaries in children and the frequency of conjunctival haemorrhage in newborn infants.

The striking parallelism of the four curves suggests that the seasonal variation in the frequency

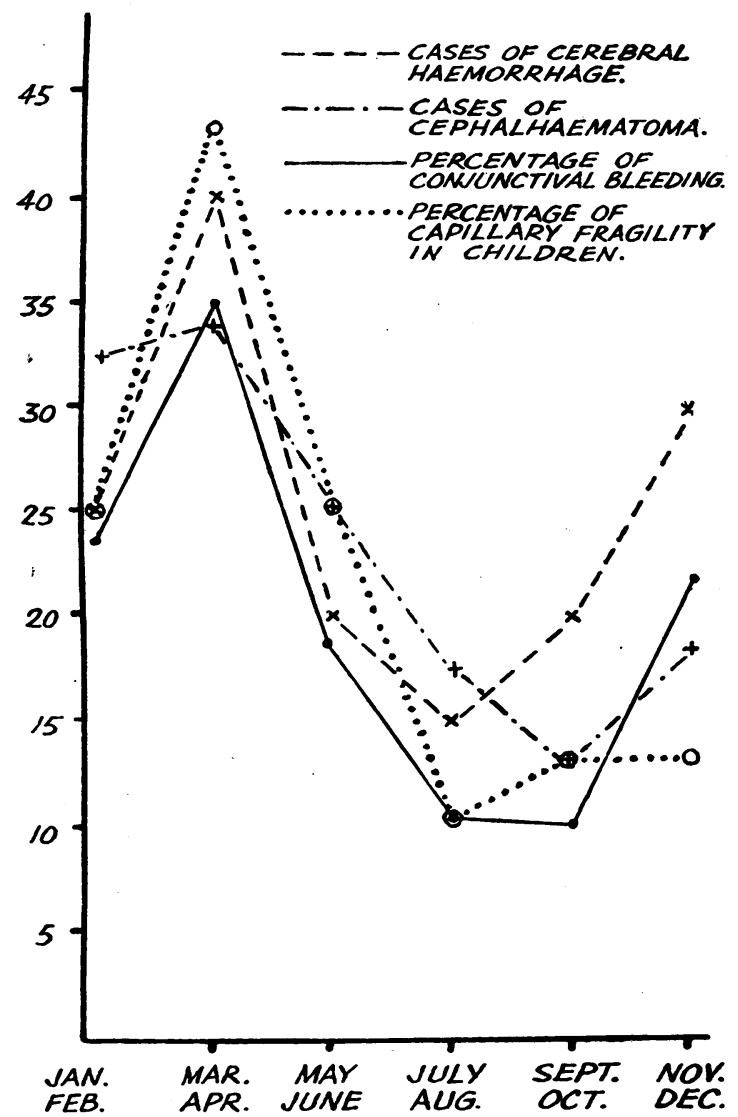

of haemorrhagic tendency in the newborn infant is linked with the seasonal variation in the fragility of the capillaries. In other words, on the basis of the parallelism of the four curves, we feel that in winter and spring a greater number of infants are born with fragile capillaries than in summer and autumn; accordingly a trauma of constant intensity will result in a higher incidence of birth haemorrhages in the former seasons.

A contributory cause to this peculiar seasonal incidence of birth injury seems to be the prothrombin deficiency occurring, as has been said, with greater frequency in those seasons when capillary resistance is at its lowest. The parallelism in the seasonal decrease in prothrombin level and in capillary resistance is suggestive of a simultaneous deficiency both of vitamin $K$ and vitamin $P$ in the maternal diet in winter and spring.

\section{Capillary Permeability}

The striking seasonal fluctuation in capillary fragility, described above, suggested the extension of our studies to the examination of seasonal variation in capillary permeability.

The method of Landis' et al. (1932) was used for testing the permeability. A positive pressure of $40 \mathrm{~mm}$. Hg. was applied for thirty minutes to one arm, and blood was then drawn from the veins of both arms. The difference in haematocrit readings or red cell counts of the blood taken from both arms permits the calculation of the amount of fluid escaping from the compressed arm. Under these experimental conditions the amount of this fluid should normally never exceed $6 \mathrm{ml}$. (Landis et al., 1932; Eppinger, 1935; Armentano, 1940; Gömöri et al., 1947).

In sixty cases of both fragile and resistant capillaries normal capillary permeability was found. The amount of the fluid reached $6 \mathrm{ml}$. in only two instances; in the remaining fifty-eight cases it was less than $3 \mathrm{ml}$. The fluid contained no proteins.

This negative result suggested the examination of capillary fragility in cases showing pathological increase of capillary permeability. This comparative study of permeability and fragility was carried out on four infants suffering from intestinal toxicosis. The figures are demonstrated in table 2.

The data show that even a considerable increase in permeability may occur without any influence on resistance. This lack of parallelism between pathologic permeability and fragility of the capillaries suggests that the underlying cause for the pathologic changes in increased permeability and increased fragility is different. In the origin of increased fragility lack of vitamin P (Armentano et al., 1936; Rusznyák and Szent-Györgyi, 1936; Zacho, 1939; Scarborough, 1940; Rapaport, 1941; Bicknell and Prescott, 1946) has been described as of outstanding importance. Less is known about increased permeability. It seems that toxic or bacterial damage to the capillaries results in the increase of their permeability (Kerpel-Fronius, 1947). A detailed 
TABLE 2

CAPILLARY PERMEABILITY AND FRAGILITY

\begin{tabular}{l|c|c|c|c}
\hline Diagnosis & $\begin{array}{c}\text { Amount of } \\
\text { escaped fluid } \\
\text { (ml.) }\end{array}$ & $\begin{array}{c}\text { Protein content } \\
\text { of escaped } \\
\text { fluid (per cent.) }\end{array}$ & $\begin{array}{c}\text { Borbsly's } \\
\text { Test } \\
\text { (Hg. cm.) }\end{array}$ & $\begin{array}{c}\text { Rumpel- } \\
\text { Leede }\end{array}$ \\
\hline Toxicosis & 19 & $5 \cdot 37$ & 20 & - \\
\hline Toxicosis & 18 & not determined & 20 & - \\
\hline Toxicosis & 22 & $4 \cdot 5$ & 25 & - \\
\hline Toxicosis & 20 & not determined & 25 & - \\
\hline
\end{tabular}

discussion of the latter problem, however, is not the purpose of this paper.

\section{Summary and Conclusions}

Capillary fragility shows a decided seasonal variation, while capillary permeability is not influenced by the seasons.

The higher frequency of cephalhaematomata and cerebral haemorrhage in winter and spring seems to be linked with a parallel seasonal variation in capillary fragility and prothrombin deficiency. The parallelism in the seasonal decrease in prothrombin level and in capillary resistance suggests a simultaneous deficiency of both vitamins $K$ and $P$ in the maternal diet during winter and spring. As a prophylactic measure, therefore, it is suggested that vitamins $K$ and $P$ should be given simultaneously during the last months of pregnancy.

\section{REFERENCES}

Armentano, L. (1940). Z. ges. exp. Med., 107, 9. Bentsath, A., Rusznyák, S. and Szent-Györgyi, A. (1936). Dtsch. med. Wsch., 62, 1325.

Bicknell, F. and Prescott, F. (1946). The Vitamins in Medicine. London.

Borbély, F. von. (1930). Munch. med. Wschr., 2, 886.

Dyggve, H. (1947). Fifth Internat. Congress of Pediatrics. New York.

Eppinger, H., et al. (1935). Die seröse Entzundung, Springer, Vienna.

Gömöri, P., Grenier, A. and Pregun, A. (1947). Magyar Belorv. Arch., 1, 11.

Hirano, H. (1932). Orient. J. Dis. Child., 12, 11.

Kepila, A., and Leppo, E. (1937). Acta. Paediatr. Stock., 21, 208.

Kerpel-Fronius, E. (1944). Arch. Kinderheilk., 132, 1. (1947). Fifth Internat. Cong. of Pediatrics. New York.

Landis, E. M., Jonas, L., Angevine, M. and Erb, W. (1932). J. clin. Invest., 11, 717.

Lehmann, J. (1944). Lancet, 1, 493.

McCollum, J. L. (1928). Canad. med. Ass. J., 18, 550.

Rapaport, H. G. (1941). J. Pediat., 18, 321

Roberts, L. J., Blair, R. and Bailey, M. (1937). J. Pediat., 11, 626.

Rusznyák, S. and Szent-Györgyi, A. (1936). Nature, 138, 27.

Scarborough, H. (1940). Lancet, 11, 644

Snelling, C. E. and Nelson, W. (1943). J. Pediat., $22,77$.

Waddell, W. W. Jr. and Lawson, G. M. (1940). J. Amer. med. Ass., 115, 1416.

Willi, H. (1942). Ann. Paediatr., Basel, 159, 282.

Winkler, H. (1939). Geburtsh. Gynëk., 119, 195.

Zacho, C. E. (1939). Acta path. scand. Jobenhaven, $16,144$. 